\title{
PENGARUH KUALITAS PEGAWAI TERHADAP EFISIENSI KERJA PEGAWAI PROGRAM STUDI KEDOKTERAN GIGI UNIVERSITAS SRIWIJAYA PALEMBANG
}

\author{
Yofitri Heny Wahyuli \\ Sekolah Tinggi Ilmu Administrasi (STIA) Satya Negara Palembang \\ Email : vivin_khanza@yahoo.com
}

\begin{abstract}
ABSTRAK
Penelitian ini berjudul "Pengaruh Kualitas Pegawai terhadap Efisiensi Kerja Pegawai Program Studi Kedokteran Gigi Universitas Sriwijaya Palembang".Penelitian ini dilakukan di Kota Palembang, khususnya di wilayah Universitas Sriwijaya Palembang.Tujuan penelitian ini adalah untuk mengetahuiapakah terdapat hubungan yang signifikan antara kualitas pegawai dengan efisiensi kerja di Program Studi Kedokteran Gigi Universitas Sriwijaya Palembang dan untuk mengetahui Tingkat Kualitas Pegawai dan Efisiensi Kerja Pegawai Program Studi Kedokteran Gigi Universitas Sriwijaya secara keseluruhan. Penelitian ini menggunakan teknik analisis data kuantitatif. Penafsiran terhadap hasil penelitian disesuaikan dengan pedoman pada teori yang sesuai.

Dari hasil penelitian ini dapat disimpulkan : bahwa kualitas pegawai pada fakultas kedokteran Universitas Sriwijaya adalah tergolong baik. Hal itu biasa dilihat dari perolehan nilai seluruh pertanyaan sebesar 128 yang menunjukkan hasil yang baik.Tingkat efisiensi kerja pegawai pada fakultas kedokteran Universitas Sriwijaya variabel efisiensi kerja pegawai berdasarkan hasil penelitian dapat disimpulkan bahwa efisiensi kerja pegawai tergolong tinggi. Hal itu dapat terlihat dari nilai rata-rata untuk variabel efisiensi kerja (Y) sebesar 14.415 yang menunjukkan hasil yang tinggi. pengaruh kualitas pegawai terhadap efisiensi kerja pegawai fakultas kedokteran Universitas Sriwijaya. Besar hubungan antar variabel kualitas pegawai (X) dengan efisiensi kerja pegawai (Y) adalah $-0,720$ dengan nilai signifikansi sebesar 0.001 . Hal ini menunjukkan korelasi yang kuat antara kualitas pegawai dengan efisiensi kerja pegawai. Dari perhitungan ternyata baik dari perhitungan korelasi, koefisien determinasi dan uji t diperoleh simpulan variabel bebas memiliki pengaruh positif, searah dan signifikansi terhadap efisiensi kerja.Di dukung oleh hasil uji t yang menunjukkan ditolaknya Ho. Pengaruh arah yang positif artinya jika variabel kualitas pegawai ditingkatkan maka variabel maka efisiensi kerja pegawai pun mengalami peningkatan. Begitu juga sebaliknya jika variabel bebas tersebut mengalami penurunan, maka akan diikuti dengan penurunan pada variabel efisiensi kerja pegawai.
\end{abstract}

Kata Kunci : Efisiensi Kerja Pegawai, Kualitas Pegawai

\section{PENDAHULUAN}

\subsection{Latar Belakang}

Penelitian ini dilatar belakangi oleh pemikiran bahwa masalah kepegawaian merupakan masalah yang sangat penting dan menentukan dalam kelancaran mekanisme pemerintahan dan keberhasilan pelaksanaan pembangunan yang merata. Lebih lanjut dalam Undang-Undang Nomor 8 Tahun 1974 lebih ditegaskan dinyatakan :
"Kedudukan dan peranan pegawai negeri adalah penting dan menentukan karena pegawai negeri adalah unsur aparatur negara untuk menyelenggarakan pemerintahan dan pembangunan dalam rangka usaha pencapaian tujuan nasional."

Oleh karena itu, tuntutan akan pegawai yang sangat berkualitas menjadi prioritas untuk menjadi abdi negara. Mengingat pentingnya peranan pegawai yang berkualitas sebagai unsur aparatur pemerintahan atau Negara, maka sangat 
disayangkan kalau ternyata masih banyak belum menunjukan kualitas yang baik.

MenurutSondang P. Siagian (2002 : 151) terhadap pegawai negeri orde lama sebagai berikut :Pegawai negeri kurang berperan aktif dalam bidang pembangunan kerena adanya berbagai pertentangan politik, penyalahgunaan kekuasaan, hubungan kerja yang kabur dan tidak adanya perumusan mengenai lembaga-lembaga negara.

Penciptaan kualitas manusia lebih diarahkan kepada tugas yang diembannya dalam melangsungkan hidup kehidupan. Bila dihubungkan dengan sistem kepegawaian maka penciptaan pegawai yang berkualitas diarahkan kepada efisien kerja yang diembannya.Manusia sebagai subjek pembanguan merupakan pelaku atau orang melakukan proses kerja sama dalam mencapai tujuan, manusia sebagai pelaku pembangunan. Manusia sebagai objek pembangunan merupakan penciptaan manusia seutuhnya yakni pembangunan mental dan spiritual manusia.

Berdasarkan peryataan di atas dapat diketahui bahwa di lingkungan pegawai negeri ternyata menujukan adanya cara kerja yang mengarah pada kualitasnya yang tidak semua pegawai miliki sama. Dengan keadaan aparat yang kurang berkualitas jelas akan menghambat dalam melayani dan memenuhi kebutuhan masyarakat.

Gejala yang nampak pada kantorKedokteran Gigi Unsri Palembang saat ini adalah peningkatan mutu pegawai sesuai jabatannnya dilakukan melalui pendidikan dan pelatihan tidak dapat dilakukan serentak oleh setiap pegawai.

Pegawai yang berkualitas akan membantu atau menutupi kelemahan kerja pegawai yang lainnya. Sehingga nampak kerja kelompok dapat dicapai secara efisien. Pada kenyataannya menujukkan bahwa kualitas pegawai perseorangan akan mempengaruhi efisiensi kerjanya.

\subsection{Rumusan Masalah}

Bertitik tolak latar belakang masalah dapat maka permasalahan dalam penelitian ini yaitu :

a. Apakah ada hubungan yang signifikan antara kualitas pegawai dengan efisiensi kerja pegawai Program Studi Kedokteran Gigi Universitas Sriwijaya ?

b. Apakah ada pengaruh antara kualitas pegawai terhadap efisiensi kerja pegawai Program Studi Kedokteran Gigi Universitas Sriwijaya?

\subsection{Tujuan Penelitian}

a. Untuk mengetahui apakah terdapat hubungan yang signifikan antara kualitas pegawai dengan efisiensi kerja di Program Studi Kedokteran Gigi Universitas Sriwijaya

b. Untuk mengetahui tingkat kualitas pegawai dan efisiensi kerja pegawai Program Studi Kedokteran Gigi Universitas Sriwijaya secara keseluruhan.

\subsection{Manfaat penelitian}

Penelitian ini diharapkan dapat bermanfaat untuk semua pihak yaitu :

1. Sebagai referensibagi masyarakat melakukan penelitian untuk kualitas pegawai dan efisiensi kerja.

2. Sebagai bahan bacaan masyarakat untuk menambah cakrawala ilmu pengetahuan masyarakat tentang kualitas pegawai dan efisiensi kerja

\section{LANDASAN TEORI}

\subsection{Pengertian kualitas pegawai}

Kualitas pegawai terdiri dari dua kata yakni ; kualitas dan pegawai.bila kedua kata tersebut diuraikan terpisah, 
dalam kamus umum bahasa Indonesia kata kualitas adalah kualitet.

Sedangkan dalam kamus Indonesia penggertian kualitas adalah sebagai berikut ;Quality1. Mutu, kualitas.2.Sifat Menurut PP No. 59/1951 pasal 1 huruf (a) peraturan tentang pengangkatan Pegawai NegeriL. N. No. 89/1951 berbunyi ; "pegawai adalah orang yang memegang jabatan negeri tidak bersifat sementara dan gajinya dibayar dari Anggaran Negara menurut peraturan gaji yang berlaku.

Menurut Undang-undang No. 8/1974 tentang Pokok-Pokok Kepegawaian pasal 1 huruf (a) yang berbunyi :"Pegawai negeri adalah mereka yang telah memenuhi syarat-syarat yang telah ditentukan dalam peraturan perudangan-undangan yang berlaku, diangkatnya oleh pejabat yang berwenang dan serahi tugas dalam jabatan negeri/serahi tugas Negara lainnya yang ditetapkan berdasarkan undang-undang atau peraturan dan digaji menurut perudangan-undang yang berlaku.

Walaupun dari pengertianpengertian di atas terdapat perbedaan perumusan, namun pada hakekatnya mempunyai maksud yang sama, Pegawai adalah mereka yang telah memenuhi persyaratan yang telah di tentukan, diangkat dan diserahi tugas dalam jabatan negeri serta digaji menurut peraturan perudangan yang berlaku.

\subsection{Pengertian Efisiensi Kerja}

Dalam penelitian ini, penulis mengambil konsep yang diberikan oleh The Liang Gie (2001 : 34), karena efisiensi kerja pada dasarnya mempunyai dua rangkaian kata, efisiensi yang berarti perbandingan terbaik antara masukan dengan pengeluaran, sedangkan kerja mengadung arti usaha, kegiatan atau proses melakukan.

Jadi dapat dikatakan bahwa efisiensi adalah menemukan suatu cara untuk mencegah pemborosan, baik pemborosan tenaga maupun pemborosan waktu dan alat-alat yang dipergunakan untuk melaksanakan suatu tugas tertentu.

\section{METODE PENELITIAN}

\subsection{Ruang Lingkup Penelitian}

Jenis penelitian yang digunakan untuh mengolah dan menganalisis data yang ada agar tujuan penelitian dapat tercapai adalah melalui penelitian deskriptif kuantitatif. Yaitu penelitian yang mengambil sampel dari populasi dengan menggunakan kuesioner sebagai alat pengumpul data utama. Dengan tujuan untuk memperoleh informasi pengaruh antara kualitas pegawai terhadap efisiensi kerja pegawai Program Studi Kedokteran Gigi Universitas Sriwija

Menurut Husein Umar (2001:81) sebagai berikut:“Metode deskriptif bertujuan untuk menggambarkan sifat sesuatu yang tengah berlangsung pada saat tertentu dilakukan dan memeriksa sebab.Model penelitian yang digunakan adalah penelitian deskriptif kuantitatif. adalah penelitian yang dilakukan untuk mengetahui nilai variabel baik satu variabel atau lebih (independen) tanpa membuat perbandingan, atau menghubungkan dengan variabel yang lain

\subsection{Variabel Penelitian}

Pada penelitian ini menggunakan dua jenis variabel, yaitu: variabel bebas (variabel $\mathrm{X}$ ) dan variabel terikat (variabel Y).

Adapun jenis variabel tersebut :

1. Variabel Bebas (X)

Dalam penelitian ini variabel bebasnya yaitu:Kualitas pegawai

2. Variabel Terikat $(\mathrm{Y})$ 
Dalam penelitian ini variabel terikatnya yaitu:efisiensiKerja (Y)

\section{Definisi Operasional}

Mengacu pada pendapat G.Tan yang dikutip oleh Koentjaraningrat (2007 :5), maka kualitas pegawai dalam penelitian ini diukur berdasarkan, empat dimensi yaitu : komunikasi, interpersonal, kreativitas dan tim kerja; secara rinci indikator untuk masing-masing dimensi dijelaskan sebagai berikut :

Tabel 3.1

Dimensi dan Indikator Kualitas Pegawai

\begin{tabular}{|l|l|l|l|}
\hline \multicolumn{1}{|c|}{ Dimensi } & \multicolumn{1}{|c|}{ Indikator } & Butir & $\begin{array}{c}\text { Jumlah } \\
\text { Butir }\end{array}$ \\
\hline Kualitas pegawai & \multicolumn{1}{|c|}{$\begin{array}{l}\text { 1.1 Komunikasi baik dengan } \\
\text { dengan rekan kerja dan bawahan } \\
1.2 \text { Alat untuk mencetuskan ide-ide } \\
1.3 \text { Memperluas jaringan }\end{array}$} & $1,2,5,9$ & 4 \\
\hline 1. Komunikasi & $\begin{array}{l}\text { 2.1 Membantu teman yang } \\
\text { membutuhkan bantuan } \\
2.2 \text { dengan teman dan klien }\end{array}$ & $\begin{array}{l}6,11, \\
12,13\end{array}$ & 4 \\
\hline 2. Interpersonal & $\begin{array}{l}\text { 3.1 Mengerjakan pekerjaan dengan } \\
\text { cepat dan tepat } \\
\text { 3.2 Percaya akan kemampuan diri }\end{array}$ & $\begin{array}{l}4,9,10,1 \\
5\end{array}$ & 4 \\
\hline 4. Tim Kerja & $\begin{array}{l}\text { 4.1 Memotivasi tim untuk tidak } \\
\text { pantang menyerah } \\
\text { 4.2 Bekerja bersama tim menuntut } \\
\text { kreativitas }\end{array}$ & $8,3,14$, & 3 \\
\hline
\end{tabular}

Setiap pertanyaan kuesioner diberikan bobot dengan menggunakan skala likert.

Menurut Sugiyono (2006:87), skala likert adalah alat ukur yang dipakai untuk mengukur sikap, pendapat, dan persepsi seseorang atau sekelompok orang tentang fenomena sosial.

\subsection{Populasi dan Sampel}

\section{Populasi}

Populasi dalam penelitian ini adalahseluruh pegawai program studi kedokteran Gigi Universitas Sriwijaya yang terdiri dari 4 bidang kerja, berjumlah 50 orang pegawai.

\section{Sampel}

Untuk memperoleh data sebagai bahan analisis dalam penelitian ini digunakan responden yaitu orang yang memberikan informasi sesuai dengan permintaan/pertanyaan yang diajukan.penentuan responden dengan sistem sampling quota. Oleh sebab itulah kuota dalam penelitian ini dibatasi hanya pada pegawai yang ada di program studi kedokteran Gigi Universitas Sriwijaya berjumlah 50 orang

\subsection{Teknik Pengumpulan Data}

Teknik pengumpulan data yang dipergunakan dalam penelitian ini adalah:

a. Observasi

Observasi yaitu melakukan pengamatan terhadap objek penelitian untuk memperoleh data yang dibatasi sejumlah variabel/subvariabel. 
b. Kuesioner (angket)

Peneliti mengumpulkan data dengan mengajukan daftar pertanyaan yang telah disiapkan berkaitan dengan variabel kualitas pegawai, dan efisiensi kerja, kemudian menyampaikannya kepada responden adalah dijawab secara tertulis.

c. Penelitian Kepustakaan (Library Research)

Penelitian ini dimaksudkan untuk memperoleh data yang bersifat teoritis yaitu dilakukan dengan mengumpulkan bahan-bahan dari buku-buku, literaturliteratur, dan referensi yang berkaitan dengan judul skripsi yang terdapat di perpustakaan.

3.5. Kerangka Pemikiran
Untuk Mempermudah pemahaman tentang penelitian ini maka akan digambarkan kerangka pemikiran

Gambar 3.1.

Kerangka Penelitian

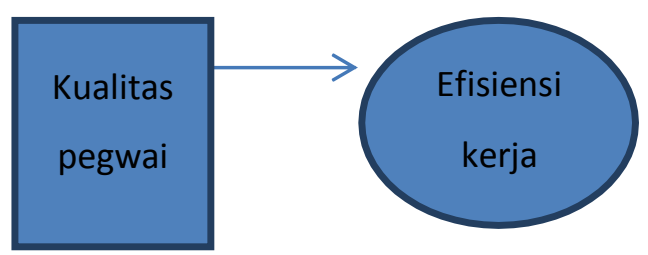

\section{HASIL PENELITIAN}

\subsection{Tabulasi Hasil Kuesioner}

Berikut ini adalah tabulasi kuesioner yang berkenaan dengan variable kualitas pegawai, yang mencakup seluruh jawaban responden terhadap indikatorindikator kualitas pegawai yang telah dirumuskan sebelumnya.

Tabel.4.1

Jawaban responden terhadap variabel

Kualitas pegawai berdasarkan Skala Likert

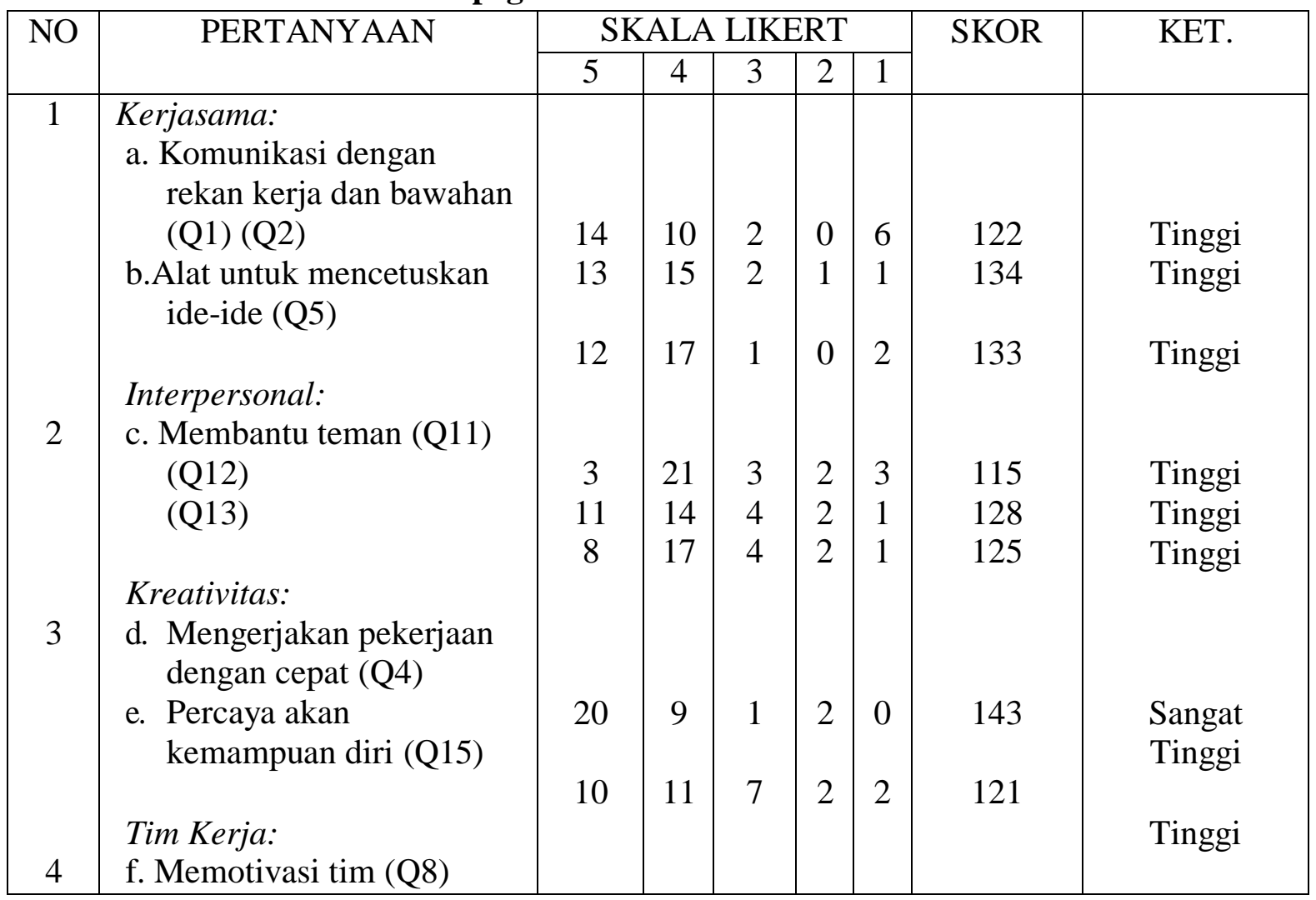




\begin{tabular}{|l|l|c|c|c|c|c|c|c|}
\hline $\begin{array}{l}\text { g. Bekerja bersama tim } \\
\text { menuntut kreativitas } \\
(\mathrm{Q} 14)\end{array}$ & 9 & 17 & 4 & 1 & 1 & 128 & Tinggi \\
\hline & 9 & 19 & 3 & 0 & 1 & 131 & Tinggi \\
\hline Jumlah & Rata-rata & & $\mathbf{1 2 8 0}$ & \\
\hline
\end{tabular}

Sumber: Data Olahan Hasil Jawaban Kuesioner, 2012

Gambar 5.1

Perolehan hasil kuesioner Kualitas pegawai

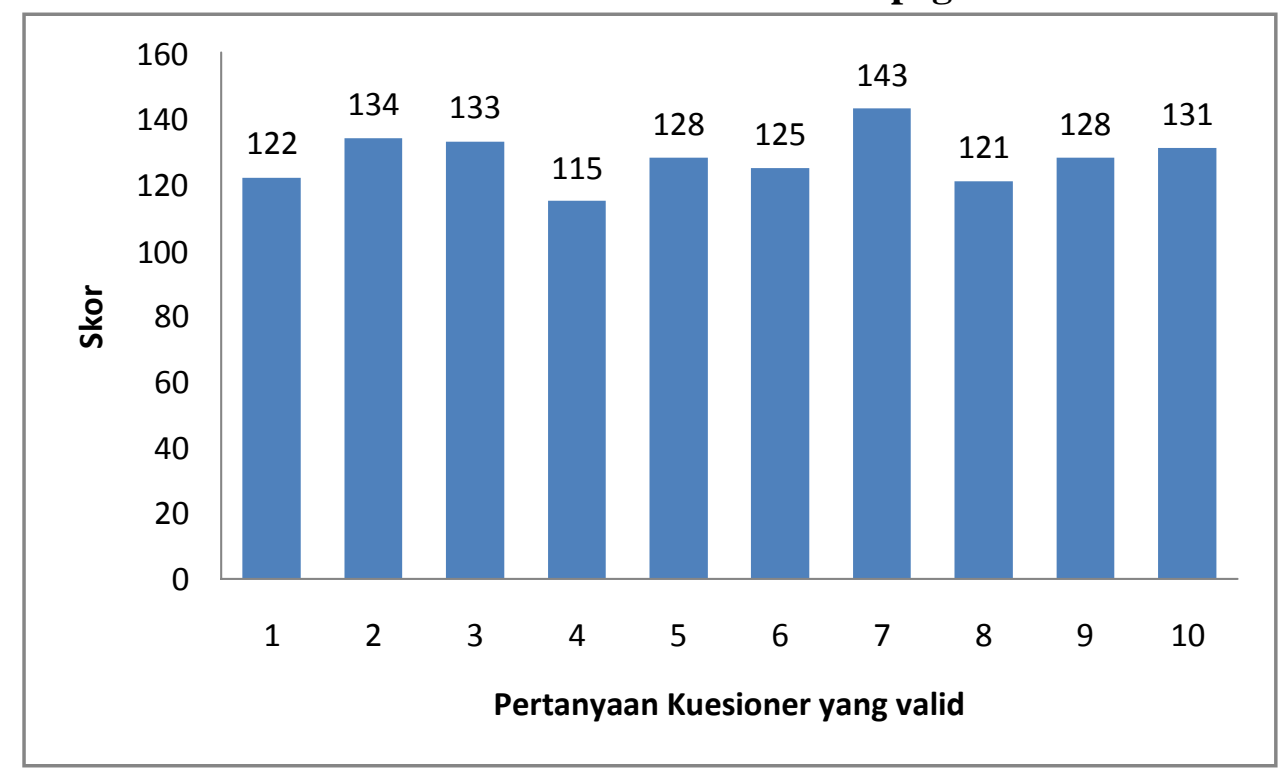

Berdasarkan jawaban dari responden di atas, salah-satu pertanyaan kreativitas memiliki nilai yang tinggi.

\subsection{Uji korelasi}

Tabel 4.2.

Hasil Uji Korelasi

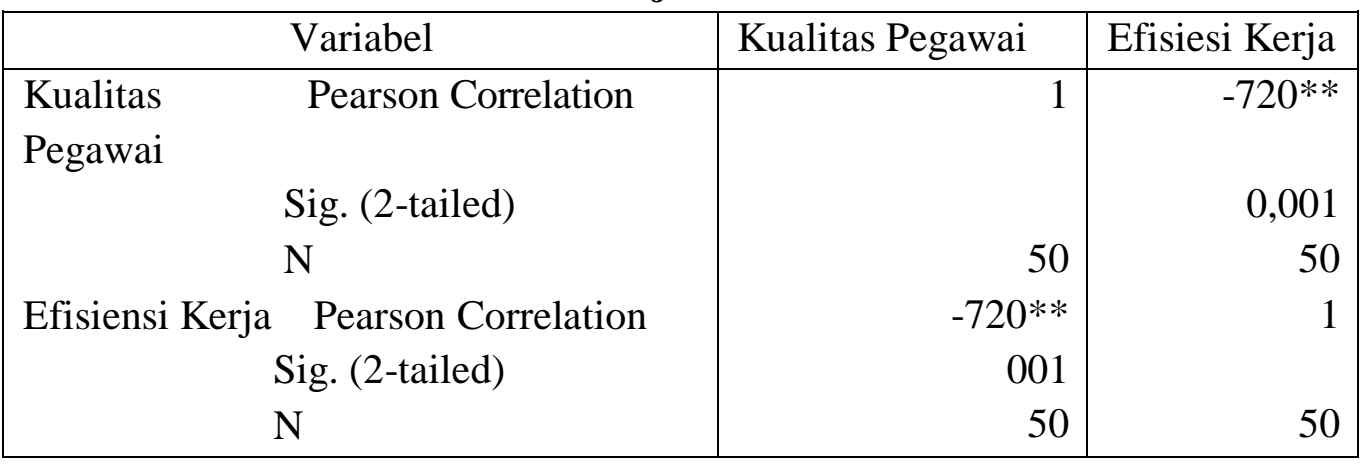

** Correlation is significant at be 0.001 level (2-tailed)

Dari hasil korelasi di atas interpretasinya adalah sebagai berikut: a. Variabel kualitas pegawai memilki nilai hubungan dengan efisiensi kerja pegawai sebesar $-0,720$ (minus) dengan 
nilai signifikansi sebesar 0.001 ternyata hubungan variabel $\mathrm{X}$ dan $\mathrm{Y}$ memiliki nilai signifikansi bawah 0.005 dengan tanda negative. Hal ini menunjukkan terdapat hubungan negativ dan signifikan yang kuat.

b. Hubungan yang positif dan signifikan menunjukkan bahwa terdapat hubungan antara variable kualitas pegawai dengan variable efisiensi kerja pegawai. Jika variable kualitas pegawai rendah maka akan diikuti dengan efisiensi kerja pegawai yang rendah, begitu juga sebaliknya jika kualitas pegawai kerja tinggi maka akan dikuti dengan efisiensi kerja pegawai yang tinggi.

\section{Uji KoefisienDeterminasi (KD)}

Uji koefisien determinasi digunakan untuk mengetahui persentase hubungan antara variabel $\mathrm{X}$ dan $\mathrm{Y}$

Tabel.4.3

HasilUji R Square

Model Summary

\begin{tabular}{|c|r|r|r|r|}
\hline Model & R & R Square & $\begin{array}{r}\text { Adjusted } \\
\text { R.Square }\end{array}$ & $\begin{array}{r}\text { Std Error of } \\
\text { the Estimate }\end{array}$ \\
\hline 1 & $\mathbf{- 7 2 0}^{\mathbf{a}}$ & $\mathbf{0 . 5 1 8}$ & $\mathbf{0 . 5 1 8}$ & $\mathbf{3 . 6 9 7 5 1}$ \\
\hline
\end{tabular}

Predictor : (constanst), Kualitas Pegawai

Output"model summary'berfungsi sebagai output untuk uji koefisien Determinasi atau koefisien penentu, yaitu kuadrat dari nilai korelasi ( $R$ Square). Diperoleh nilai $R$ Square sebesar 0.518.hal itu menunjukkan persentase hubungan variabel kualitas pegawai dengan efisiensi kerja pegawai adalah sebesar $51.8 \%$ sedangkan sisanya sebesar $48,2 \%$ adalah dari faktor lain seperti lingkungan kerja dan sebagainya. Dengan demikian dari persentase hubungan masih dapat dikatakan kuat karena berada di atas 50\% sedangkan sisanya merupakan kontribusi dari faktor-faktor lain yang mempengaruhi efisiensi kerja pegawai

\subsection{Uji t}

Uji $t$ dapat dilakukan untk menguji hipotesis penelitian

Diketahui :

Ho : Kualitas pegawai tidak memiliki hubungan signifikan dengan efisiensi kerja pegawai

Ha : Kualitas pegawai memiliki hubungan signifikan dengan efisiensi kerja pegawai

Kriteria pengujian manual :

Ho diterima jika $t$ hitung $<\mathrm{t}$ tabel

Ho di tolak diterima jika $\mathrm{t}$ hitung $>\mathrm{t}$ tabel

Kriteria pengujian melalui SPSS

Ho diterima jika nilai Sig. $>0.05$

Ho ditolak jika nilai Sig. $<0.05$

Tabel3.4.

Hasil Uji Signifikansi (uji t)

Coefficients

\begin{tabular}{|c|c|c|c|c|c|}
\hline \multirow[b]{2}{*}{ Model } & \multicolumn{2}{|c|}{$\begin{array}{c}\text { Unstandarized } \\
\text { Coefficients }\end{array}$} & \multirow{2}{*}{$\begin{array}{c}\begin{array}{c}\text { standarized } \\
\text { Coefficients }\end{array} \\
\text { Beta }\end{array}$} & \multirow[b]{2}{*}{$\mathrm{t}$} & \multirow[b]{2}{*}{ Sig. } \\
\hline & $\mathrm{B}$ & Std. Error & & & \\
\hline $\begin{array}{l}1 \\
\text { (Constant) }\end{array}$ & $\begin{array}{r}38.666 \\
-720\end{array}$ & $\begin{array}{l}2.682 \\
0.144\end{array}$ & -720 & $\begin{array}{l}14.415 \\
-4.139\end{array}$ & $\begin{array}{r}000 \\
.0 .001\end{array}$ \\
\hline
\end{tabular}




\begin{tabular}{|l|l|l|l|l|l|}
\hline $\begin{array}{l}\text { Efisiensi } \\
\text { kerja }\end{array}$ & & & & & \\
\hline
\end{tabular}

Dependent Variable : Efisiensi kerja

Dari perhitungan uji $\mathrm{t}$ di atas diperoleh nilai $\mathrm{t}$ hitung sebesar -4.139 dengan nilai Sig sebesar0.001.ternyata nilai Sig.<,05. Maka Ho di tolak menunjukkan variabel kualitas pegawai memiliki hubungan yang positif dan signifikan dengan efisiensi kerja pegawai.

\section{PEMBAHASAN}

Dari berbagai perhitungan di atas ternyata baik dari perhitungan korelasi, uji koefisien dan uji $\mathrm{t}$ diperoleh simpulan bahwa variabel bebas(kualitas pegawai) memiliki hubungan yang positif dan signifikan dengan efisiensi kerja pegawai. Hubungan yang negative dan tidak signifikan menunjukkan hubungan antara kualitas pegawai dengan efisiensi kerja pegawai. Hubungan yang berlawanan artinta jika variabel kualitas pegawai tinggi akan diikuti dengan efisiensi kerja pegawai yang tinggi, begitu juga sebaliknya jika kualitas pegawai rendah maka, akan diikuti dengan efisiensi kerja pegawai yang rendah.

Dengan demikian hal itu memberikan implikasi, jika di fakultas kedokteran gigi Universitas Sriwijaya bermaksud meningkatkan efisiensi kerja pegawai, maka harus menekan tingkat kualitas pegawai yang terkait dengan faktor-faktor yang tercantum pada indicator yaitu : konflik kerja, beban kerja, karakteristik tugas dan pola kepemimpinan yang diterapkan sebagai faktor dominan yang dapat meningkatkan efisiensi kerja pegawai. Penelitian ini berada dalam posisi mendukung teori-teori yang ada, yaitu bahwa seperti telah dibahas pada bab sebelumnya, bahwa kualitas pegawai dalam suatu organisasi memiliki positif dengan efisiensi kerja. Masalah kualitas pegawai di dalam organisasi difakultas kedokteran gigi Universitas Sriwijaya Palembang menjadi gejala yang penting diamati sejak mulai timbulnya tuntutan untuk efisien di dalam pekerjaan.

\section{KESIMPULAN}

Dari pembahasan yang uraikan pada bab-bab sebelumnya maka dapat disimpulkan sebagai berikut:

1. kualitas pegawai pada fakultas kedokteran Universitas Sriwijaya adalah tergolong baik. Hal itu bias dilihat dari perolehan nilai seluruh pertanyaan sebesar 128 yang menunjukkan hasil yang baik.

2. Efisiensi kerja pegawai tergolong tinggi.hal itu dapat terlihat dari nilai rata-rata untuk variabel efisiensi kerja (Y) sebesar 14.415 yang menunjukkan hasil yang tinggi

3. Besar hubungan antar variabel kualitas pegawai (X) dengan efisiensi kerja pegawai (Y) adalah -0,720 dengan nilai signifikansi sebesar 0.001. hal ini menunjukkan korelasi yang kuat antara kualitas pegawai dengan efisiensi kerja pegawai.

\section{SARAN}

Berdasarkan simpulan di atas berikut ini akan disajikan saran-saran yang terkait dengan penelitian ini sebagai berikut:

1. Hendaknya instansi meningkatkan kualitas pegawai yang optimal sehingga efisiensi kerja yang efektif 
2. Hendaknya instansi ini dapat mempertahankan hal tersebut (efisiensi) dengan mengadakan evaluasi secara berkala mengenai kualitas pegawai karena merupakan factor penting untuk meningkatkan efisiensi kerja pegawai

3. Agar kiranya fakultas kedokteran Universitas Sriwijaya tidak stagnan dalam melihat hasil kualitas pegawai dan hubungannya terhadap efisiensi kerja yang tinggi.

\section{DAFTAR PUSTAKA}

Ewin B. Flippo. 2001. Manajemen. Yogyakarta : Gajah Mada

Herbert G. Hicks. 2002. Dasar-Dasar Organisasi.Jogjakarta: Gajah Mada Universitas Press.

Jhon M. Echls dan Hassan Shadily.2002.Kamus Bahasa Inggris-Indonesia.Jakarta: $\quad$ PT. Gramedia.

Kartini Kartono. 2002.Psikologi Sosial Untuk Management Perusahaan dan Industri.Jakarta : PT. Grafindo

Leonardo D.White. 2001. Dasar-Dasar Organisasi dan Manajemen.JakartaGhalia Indonesia

Masri Singarimbun. 2001. Metode Penelitian Survey LP3ES. Bandung : Alfa Beta

MiftahThoha.2004.Dimensi-DimensiPrima Administrasi Negara.Jakarta: C.V. Rajawali

Muhammad Nazir.2003. Metode Penelitian.Jakarta : Ghalia Indonesia

Ralp Barra,2003.Menerapkan Gugus Mutu. Jakarta : Erlangga

SoerwarnoHadayaningrat.2002Pengantar Studi Ilmu Administrasi dan Manajemen.Jakarta : Erlangga

Sondang P. Siagian.2003.Filsafat Administrasi.Jakarta : CV Haji
Agung Sondang P. Siagian. 2002. Administrasi Pembangunan. Jakarta: Gunung Agung

Suharsimi Ari kunto.2002.Prosedur Penelitian Suatu Pendekatan Praktis. Jakarta : Bina Aksara.

Sukarna.2001.Administrasi Negara.Bandung: Ganexa EcxatThe Liang Gie. 2003. Administrasi Perkantoran Modern. Jakarta : Bina Aksara

Winarno Surachman.2002. Dasar dan Tehnik Research, Pengantar Metodelogi Ilmiah.Tarsito Bandung: Ganexa Ecxat 